\title{
Influence of barley variety and growing locality on the profile of flavonoid polyphenols in malt
}

\author{
Alexandr Mikyška*, Martin Dušek, Pavel Čejka \\ Research Institute of Brewing and Malting, Lípová 15, \\ 12044 Prague, Czech Republic
}

*Corresponding author: mikyska@beerresearch.cz

\begin{abstract}
Some polyphenol substances are important for beer production as well as for the health benefits of beer consumption. Hop polyphenols have been relatively well researched in the last decade, less attention has been paid to malt. Our study was aimed to determine the influence of the barley variety and growing locality on the profile of proanthocyanidins (PAC), monomeric flavanols, flavonols and their glycosides in malt. Laboratory malts from three barley cultivars grown in seven countries of the European Union were analyzed by the developed LC-HR / MS method with sample preparation by the QuEChERS technique. Dimers of (epi)catechin (37.0\%) and dimers (epi)catechin - (epi) gallocatechin (36.4\%) dominate the PAC profile of malt, monomer content being low. Flavanols (epi)catechin and (epi)catechin-O-glucoside have been identified and quantified in malts. The flavonols were quercetin and myricetin, their glycosides were not detected. The results suggest varietal dependence of the PAC, monomeric flavanols and flavonols profile and the lesser impact of the growing locality.
\end{abstract}

Keywords: antioxidants, flavonoids, proanthocyanidins, barley, malt

\section{Introduction}

Polyphenol substances have an impact on beer quality, colloidal and sensory stability (Aron and Shellhammer 2010, Callemien and Collin 2010). This is a very diversified group of compounds whose individual components differ considerably in their chemical structure and therefore have different properties in terms of antioxidant radical scavenging and metal chelating abilities and other biological functions. Some simple and more complex polyphenols and their oxidation products are sensory active, affecting the bitterness and astringency of beer (Callemien et al., 2005; Oladokun et al., 2016, McLaughlin et al., 2008). Both hops and malt are a source of polyphenol antioxidants with potential or proven biological effects. Both raw materials contain phenolic acids, monomeric and oligomeric flavonoids, especially monomers of flavanols (e.g. catechin), oligomeric proanthocyanidins, and flavonols (e.g. quercetin). A unique group are hop prenylflavonoids with a wide spectrum of antioxidant, anticancer, estrogenic, antimicrobial and other beneficial effects
(Karabin et al., 2016). Hop polyphenols have been relatively well described in the last decade and recent review papers (Karabin et al., 2016; Bocquet et al., 2018; Bocquet et al., 2018a) summarize the current state of knowledge of the chemistry and biological effects of hop constituents. On the other hand, somewhat less attention is paid to the profile of phenolic compounds and antioxidant properties of malt - the predominant source of polyphenols in beer, where it constitutes 70 to $80 \%$ of total polyphenols (Narziss and Bellmer, 1975). Phenolic compounds in cereals are predominantly found in the outer layers of the grain (husk, pericarp, testa, and aleurone cells), while their concentration is noticeably lower in the endosperm layer (Kähkönen et al., 1999). Free, esterified and bound polyphenol compounds were found in aqueous barley and malt extracts and in extracts with $70 \%$ aqueous methanol, the major components being some phenolic acids (ferulic acid) and flavanols (catechin). The antioxidant activity of the extracts determined by the DPPH method 
was related to the polyphenol content. The content of polyphenols ranged from 0.7 to $2.5 \mathrm{mg} / \mathrm{g}$ (Dvorakova et al., 2008; Dvorakova et al., 2008a). Similarly, the relationship of antioxidant potential and total polyphenol content was demonstrated in aqueous barley and malt extracts (Mareček et al. 2017). Research on the relationship between malt chemical parameters and sensory data has shown that antiradical power of malt correlating with polyphenol content in malt is a major contribution of malt to sensory stability of beer (Guido et al., 2007).

Proanthocyanidins (PAC), also known as condensed tannins, are flavan-3-ol oligomers and polymers that provide anthocyanidins after acid depolymerization (Basařová et al, 2010). Research into this group of polyphenols is challenging because of the lack of available standards, instability and structural complexity of especially higher oligomers, (Taylor et al, 2003). In plants, proanthocyanidins have different physiological and defensive functions. These compounds are associated with plant defense mechanisms, organoleptic properties, and potential health benefits (Merghem et al., 2004; Maatta-Riihinen et al., 2005; Oladokun et al., 2016; Karabin et al., 2016; Quinones et al., 2013; Lotito et al., 2000). Barley proanthocyanidins are composed of (epi)catechin and (epi)gallocatechin monomers forming mainly two dimeric and four trimeric procyanidins and prodelphinidins (Zimmermann and Galensa, 2007; Taylor et al. 2003).

Flavonols, especially quercetin and myricetin, as well as their glycosides such as rutin (quercetin-0-rutinoside), are considered to be very important plant polyphenol antioxidants (Karabin et al., 2016; Nowak et al., 2014). Rutin and quercetin are part of pharmaceuticals and dietary supplements. Among other plants, these compounds are contained in the hop cone mass. Even though there are not many reports of flavonol compounds in barley or barley malt, quercetin was detected in barley and malt (Dvorakova et al., 2008a) and in barley flour (Gangopadhyay et al., 2016).

Phenolic compounds in beer originate from barley malt and hops. Even though barley malt contains a much lower amount of total polyphenols per weight (50 to $100 \mathrm{mg} / 100 \mathrm{~g}$ dry matter (Narziss, 1976) than hops (up to 5,5\% of dry matter (Mikyška et al., 2012)), it still contributes $70 \%$ to $80 \%$ of total polyphenols in beer (Narziss \& Bellmer, 1975a). Thus, the content of polyphenol substances in beer depends on the raw materials used (Derdelinckx, 2008; Callemien and Collin, 2010). The increased content of polyphenols is listed as one of the characteristic features of Czech beer (total polyphenols in lager 130-230 mg/l) (Commission, 2008), which distinguishes it from foreign beers.
The aim of this pilot study was to analyze the profile of flavanols - proanthocyanidins and flavonols in selected barley varieties recommended for Czech beer and to determine the variability of studied compounds in relation to locality and variety of barley in different soil-climatic conditions.

\section{Material and methods}

The profile, content and composition of proanthocyanidins and also flavanols, flavonols and their glycosides in malt was tested by a set of three important varieties of barley (malts) recommended for Czech beer - Bojos, Laudis 550 and Petrus from seven EU countries: Czech Republic (Polná) Hungary (Jászboldogháza), Poland (Pawlowice), Netherlands, France (Verneuil), Germany (Rosenthal) and Slovakia (Nýrovce). Laboratory malts were prepared from barley grown in experimental stations by a standard procedure used at the Research Institute of Brewing and Malting for evaluation of barley varieties: steeping for 72 hours at $14^{\circ} \mathrm{C}$ with $\mathrm{CO}_{2}$ exhaustion, water $1^{\text {st }}$ day 5 hours, $2^{\text {nd }}$ day 4 hours and $3^{\text {rd }}$ day 3 hours. The germination time was 72 hours at $14^{\circ} \mathrm{C}$. Pre-drying for 12 hours at $55^{\circ} \mathrm{C}, 4$ hours of kilning at $80^{\circ} \mathrm{C}$. Malt quality parameters were determined using standard methods as described by the European Brewery Convention (Analytica EBC, 2010).

Laboratory wort for the isolation of polyphenol compounds was also prepared according to the procedure described in Analytica EBC. Flavonoids were determined in the wort matrix by liquid chromatography coupled with high resolution mass spectrometry (LCHR/MS) on a Q-Exactive instrument (Thermo Fisher Scientific, Bremen, Germany). The QuEChERS method (Anastassiades et al. 2003) was used to prepare wort samples. Flavonoids were extracted from the wort sample $(10 \mathrm{~mL})$ and acetonitrile $(10 \mathrm{~mL})$. The acetonitrile layer containing the extracted flavonoids was isolated after addition of a mixture of salts $\left(4 \mathrm{~g} \mathrm{MgSO}_{4}\right.$ and $1 \mathrm{~g} \mathrm{NaCl}$ ) followed by centrifugation ( $4500 \mathrm{rpm}, 7 \mathrm{~min}$ ). Next, a milliliter of this acetonitrile extract was first evaporated to dryness (Concentrator Plus 5305, Eppendorf, Hamburg, Germany) and then dissolved in one $\mathrm{mL}$ of methanol: water $(1: 1, \mathrm{v} / \mathrm{v})$.

Malt samples were prepared for analysis of proanthocyanidins by extraction with aqueous acetone (Dvorakova et al., 2008). To 5 grams of fine ground malt, calculated on dry weight basis, was added $250 \mathrm{~mL}$ of $70 \%$ acetone in water $(\mathrm{v} / \mathrm{v})$, shaken in an Erlenmeyer flask for 40 minutes and then filtered through a paper filter. One milliliter of the extract, as in the case of wort, was evapo- 
rated to dryness and re-dissolved in one $\mathrm{ml}$ of methanol water $(1: 1, v / v)$. The LC-HR/MS assay was performed on a XSelect HSS T3 chromatography column $(2.5 \mu \mathrm{m}$, $2.1 \times 100 \mathrm{~mm}$, Waters, Milford, MA, USA) with C18 reverse phase and the analytes were separated by gradient water elution (mobile phase A) and acetonitrile (mobile phase B) in both cases acidified by the addition of $0.1 \%$ formic acid. The chromatographic separation was carried out at a column temperature of $40{ }^{\circ} \mathrm{C}$ and the sample injection volume per column was $3 \mu \mathrm{L}$. The data was recorded by a full-scan scanning mass spectrometer over a mass range of 120 to $900 \mathrm{~m} / z$. The exact mass of the analyte of interest, calculated on the basis of the pseudomolecularion summary formulas ([M-H]'), was extracted from the measured data with a mass accuracy of $5 \mathrm{ppm}$ and further processed by TraceFinder v4.1 (Thermo Fisher Scientific, Waltham, MA, USA). The content of individual flavonoids in malt samples was quantified using an external calibration curve constructed in the range of 10 to $200 \mu \mathrm{g} / \mathrm{L}$ for all analytes of interest. Proanthocyanidin standards are, with some exceptions, commercially unavailable, the results are therefore reported in response units (peak area) corrected for internal standard.

\section{Results and discussion}

Total polyphenols: "Total polyphenols" represent the entire spectrum of polyphenol compounds contained in the matrix, phenolic acids and flavonoids. Polyphenol compounds are located in the cell walls of the grain outer layers and endosperm bound to proteins and non-starch polysaccharides. These structures are partially degraded during the germination of barley. The analytical parameters of malts varied depending on both the growing area (country) and, to a lesser extent, the variety (Table $1 \mathrm{a}, 1 \mathrm{~b}$ and $1 \mathrm{c}$ ). Total polyphenol content was in the range of 47-68 mg/100 g dry matter. The highest content was found in malts from Hungary ( $66.7 \mathrm{mg} / 100 \mathrm{~g} \mathrm{d.m}$.), the lowest in domestic malts (48.7 mg/100g d.m.). The effect of soil climatic conditions, represented by the location, was significant at $\mathrm{P}=0.016$. The trend towards higher values was in the Petrus malts, differences were significant only at $\mathrm{P}=0.06$. (Figure 1 ). Malts from the Czech Republic (CZ), Slovakia (SK) and Germany (D) under the same conditions of malting had significantly lower values of Kolbach index compared to malts from other locations. The content of total polyphenols was positively correlated with the soluble nitrogen, free amino nitrogen and relative extract at $45^{\circ} \mathrm{C}$ of the malt $(\mathrm{r}=0.55 ; \mathrm{r}=0.51 ; \mathrm{r}=0.55$, respectively; $\mathrm{P}=0.01)$ and slightly positively correlated with the Kolbach index $(r=0.36)$, the relationship to friability was inconclusive. Apparently, the releas e of phenolic compounds is mainly due to degradation of protein binding. Moreover, the higher content of soluble polyphenols in malt (wort) was associated with higher wort color $(r=0.64)$ and lower wort $\mathrm{pH}(\mathrm{r}=-0.67)$. This may be related to both the polyphenol concentration and the free amino nitrogen concentration.

Table 1a Quality parameters of malts prepared from Petrus barley variety from various European countries

\begin{tabular}{|l|c|c|c|c|c|c|c|c|}
\hline \multicolumn{1}{|c|}{ Country } & & $\mathrm{CZ}$ & $\mathrm{HU}$ & $\mathrm{PL}$ & $\mathrm{NL}$ & $\mathrm{FR}$ & $\mathrm{D}$ & SK \\
\hline Extract in dry matter & $\%$ & 82.2 & 81.0 & 81.3 & 82.2 & 83.8 & 82.8 & 81.7 \\
\hline $\mathrm{pH}$ of wort & & 5.89 & 5.74 & 5.89 & 5.86 & 5.83 & 5.93 & 5.89 \\
\hline Wort color EBC & $\mathrm{EBC}$ & 2.7 & 5.6 & 3.2 & 2.9 & 3.2 & 2.7 & 2.7 \\
\hline Diastatic power & $\mathrm{WK}$ & 471 & 350 & 453 & 454 & 426 & 563 & 468 \\
\hline Fermentability & $\%$ & 83.0 & 79.9 & 83.2 & 82.5 & 83.1 & 81.9 & 82.3 \\
\hline RE 45 ${ }^{\circ} \mathrm{C}$ & $\%$ & 35.8 & 48.0 & 45.3 & 40.4 & 40.6 & 42.1 & 39.4 \\
\hline Nitrogenous substances & $\%$ & 10.59 & 11.11 & 10.17 & 11.01 & 10.22 & 11.38 & 11.05 \\
\hline Soluble nitrogen & $\mathrm{mg} / 100 \mathrm{~mL}$ & 77.3 & 98.0 & 88.3 & 88.9 & 85.5 & 84.0 & 83.9 \\
\hline Kolbach index & $\%$ & 40.9 & 49.0 & 48.6 & 45.3 & 46.8 & 41.5 & 42.4 \\
\hline Free amino nitrogen & $\mathrm{mg} / \mathrm{L}$ & 147 & 196 & 174 & 172 & 172 & 159 & 158 \\
\hline Total polyphenols (wort) & $\mathrm{mg} / \mathrm{L}$ & 54 & 76 & 59 & 67 & 71 & 70 & 65 \\
\hline Total polyphenols (malt) & $\mathrm{mg} / 100 \mathrm{~g}$ & 48 & 67 & 53 & 60 & 63 & 63 & 58 \\
\hline Wort beta-glucan & $\mathrm{mg} / \mathrm{L}$ & 94 & 35 & 87 & 106 & 106 & 312 & 28 \\
\hline Wort arabinoxylans & $\mathrm{mg} / \mathrm{L}$ & 596 & 795 & 625 & 679 & 699 & 643 & 688 \\
\hline Friability & $\%$ & 89.6 & 95.1 & 90.4 & 81.0 & 84.8 & 74.0 & 93.0 \\
\hline
\end{tabular}

CZ - Czech Republic; HU - Hungary; PL - Poland; NL - Netherlands; FR - France ; D - Germany; SK - Slovakia 
Table 1b Quality parameters of malts prepared from Laudis 550 barley variety from various European countries

\begin{tabular}{|c|c|c|c|c|c|c|c|c|}
\hline Country & & CZ & HU & PL & NL & FR & D & SK \\
\hline Extract in dry matter & $\%$ & 82.1 & 81.5 & 82.1 & 82.1 & 83.5 & 82.9 & 81.8 \\
\hline $\mathrm{pH}$ of wort & & 5.92 & 5.81 & 5.90 & 5.92 & 5.88 & 5.97 & 5.93 \\
\hline Wort color EBC & EBC & 2.8 & 4.7 & 3.2 & 3.2 & 3.1 & 2.7 & 2.7 \\
\hline Diastatic power & WK & 328 & 357 & 350 & 331 & 343 & 374 & 358 \\
\hline Fermentability & $\%$ & 80.2 & 79.8 & 79.6 & 81.1 & 81.9 & 79.9 & 79.4 \\
\hline $\operatorname{RE} 45^{\circ} \mathrm{C}$ & $\%$ & 38.1 & 47.8 & 45.5 & 43.7 & 44.2 & 40.3 & 37.9 \\
\hline $\begin{array}{l}\text { Nitrogenous substances } \\
\text { in dry matter }\end{array}$ & $\%$ & 11.13 & 11.61 & 10.60 & 11.03 & 10.76 & 11.31 & 11.25 \\
\hline Soluble nitrogen & $\mathrm{mg} / 100 \mathrm{~mL}$ & 84.7 & 101.7 & 94.7 & 94.5 & 91.7 & 84.0 & 83.5 \\
\hline Kolbach index & $\%$ & 42.5 & 49.1 & 49.9 & 48.2 & 47.8 & 41.7 & 41.6 \\
\hline Free amino nitrogen & $\mathrm{mg} / \mathrm{L}$ & 164 & 204 & 208 & 188 & 190 & 152 & 156 \\
\hline Total polyphenols (wort) & $\mathrm{mg} / \mathrm{L}$ & 56 & 76 & 58 & 60 & 64 & 53 & 54 \\
\hline Total polyphenols (malt) & $\mathrm{mg} / 100 \mathrm{~g}$ & 50 & 68 & 52 & 53 & 57 & 47 & 48 \\
\hline Wort beta-glucan & $\mathrm{mg} / \mathrm{L}$ & 92 & 25 & 86 & 49 & 84 & 349 & 39 \\
\hline Wort arabinoxylans & $\mathrm{mg} / \mathrm{L}$ & 580 & 649 & 605 & 514 & 544 & 528 & 608 \\
\hline Friability & $\%$ & 88.0 & 94.3 & 95.5 & 87.7 & 81.4 & 78.7 & 93.6 \\
\hline
\end{tabular}

CZ - Czech Republic; HU - Hungary; PL - Poland; NL - Netherlands; FR - France; D - Germany; SK - Slovakia

Table 1c Quality parameters of malts prepared from Bojos barley variety from various European countries

\begin{tabular}{|c|c|c|c|c|c|c|c|c|}
\hline Country & & CZ & HU & PL & NL & FR & D & SK \\
\hline Extract in dry matter & $\%$ & 83.0 & 81.8 & 81.9 & 82.6 & 84.1 & 85.0 & 82.2 \\
\hline $\mathrm{pH}$ of wort & & 5.89 & 5.80 & 5.89 & 5.90 & 5.81 & 5.94 & 5.91 \\
\hline Wort color EBC & EBC & 2.8 & 5.2 & 3.2 & 3.1 & 4.2 & 2.7 & 2.8 \\
\hline Diastatic power & WK & 397 & 381 & 415 & 360 & 313 & 418 & 386 \\
\hline Fermentability & $\%$ & 80.5 & 77.4 & 79.9 & 80.3 & 79.8 & 80.4 & 78.7 \\
\hline $\operatorname{RE} 45^{\circ} \mathrm{C}$ & $\%$ & 36.3 & 46.1 & 43.9 & 42.9 & 44.1 & 41.4 & 39.0 \\
\hline $\begin{array}{l}\text { Nitrogenous substances in } \\
\text { dry matter }\end{array}$ & $\%$ & 11.12 & 11.30 & 10.96 & 10.76 & 10.55 & 10.78 & 11.88 \\
\hline Soluble nitrogen & $\mathrm{mg} / 100 \mathrm{~mL}$ & 82.0 & 107.3 & 96.4 & 92.3 & 94.5 & 85.9 & 87.7 \\
\hline Kolbach index & $\%$ & 41.3 & 52.8 & 49.3 & 48.0 & 49.9 & 44.8 & 41.3 \\
\hline Free amino nitrogen & $\mathrm{mg} / \mathrm{L}$ & 153 & 220 & 188 & 180 & 193 & 161 & 161 \\
\hline Total polyphenols (wort) & $\mathrm{mg} / \mathrm{L}$ & 54 & 74 & 63 & 51 & 56 & 53 & 63 \\
\hline Total polyphenols (malt) & $\mathrm{mg} / 100 \mathrm{~g}$ & 48 & 65 & 56 & 45 & 50 & 47 & 56 \\
\hline Wort beta-glucan & $\mathrm{mg} / \mathrm{L}$ & 101 & 24 & 86 & 50 & 84 & 193 & 27 \\
\hline Wort arabinoxylans & $\mathrm{mg} / \mathrm{L}$ & 472 & 399 & 488 & 602 & 658 & 665 & 690 \\
\hline Friability & $\%$ & 88.8 & 97.0 & 89.9 & 93.1 & 84.6 & 87.2 & 90.5 \\
\hline
\end{tabular}

CZ - Czech Republic; HU - Hungary; PL - Poland; NL - Netherlands; FR - France; D - Germany; SK - Slovakia

Proanthocyanidins (PAC): Due to their known instability, proanthocyanidins were isolated by a gentle treatment, i.e. by extraction into aqueous acetone. The results of determination of the oligomeric proanthocyanidin content profile, the "quantity" of individual catechin monomer, dimer and trimer groups according to the bound monomer units in the malts are summarized in Table 2. The results are reported in response units (peak area) corrected for internal standard. The malt extracts were found to contain, in addition to the monomers including catechin $/ \mathrm{C} /$, epicatechin $/(E) \mathrm{C} /$, gallocatechin /GC/, epigallocatechin /(E)GC/, also 5 different dimers consisting of various combinations - either catechin joined with catechin or epicatechin units linked together by $4 \alpha \rightarrow 8$ or $4 \alpha \rightarrow 6$ bond or epicatechin linked together by $4 \beta \rightarrow 8$ or $4 \beta \rightarrow 6$ bond with other epicatechin unit, or 
Table 2 Effect of variety and country of origin on concentrations of proanthocyanidin species in barley malt

\begin{tabular}{|c|c|c|c|c|c|c|c|c|c|}
\hline$\frac{\frac{\pi}{2}}{\frac{0}{50}}$ & $\begin{array}{l}\frac{Z}{E} \\
\frac{\mathrm{E}}{\vec{J}} \\
\dot{0}\end{array}$ & $\cup$ & $\underset{w}{\tilde{m}}$ & 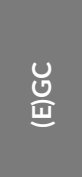 & 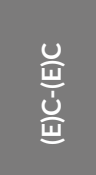 & 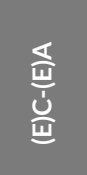 & 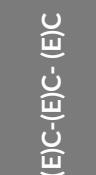 & 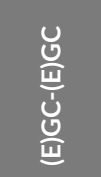 & $\begin{array}{l}\text { U⿺ } \\
\text { 产 } \\
\text { ய. }\end{array}$ \\
\hline \multirow{7}{*}{ Petrus } & $C Z$ & 64.33 & 0.00 & 6.72 & 511.43 & 12.69 & 143.41 & 88.65 & 556.10 \\
\hline & $\mathrm{HU}$ & 26.10 & 0.00 & 1.10 & 468.33 & 12.23 & 145.58 & 146.42 & 465.02 \\
\hline & PL & 37.13 & 0.00 & 13.79 & 306.86 & 3.56 & 58.86 & 214.09 & 591.89 \\
\hline & NL & 60.92 & 0.00 & 6.97 & 408.19 & 12.14 & 95.04 & 74.52 & 561.58 \\
\hline & FR & 75.00 & 0.04 & 9.63 & 500.62 & 14.29 & 117.15 & 122.77 & 606.82 \\
\hline & D & 61.82 & 0.00 & 9.77 & 463.57 & 12.40 & 113.65 & 122.34 & 592.97 \\
\hline & SK & 48.83 & 0.00 & 4.75 & 532.92 & 12.20 & 148.25 & 306.86 & 528.79 \\
\hline \multirow{7}{*}{ Laudis 550} & $C Z$ & 20.48 & 0.00 & 2.90 & 339.52 & 4.06 & 71.38 & 60.09 & 567.15 \\
\hline & $\mathrm{HU}$ & 15.21 & 0.00 & 1.15 & 376.17 & 5.76 & 104.19 & 98.09 & 495.08 \\
\hline & PL & 12.06 & 0.04 & 9.78 & 135.50 & 0.15 & 19.37 & 97.92 & 372.90 \\
\hline & $\mathrm{NL}$ & 19.89 & 0.00 & 2.72 & 346.16 & 4.75 & 79.86 & 32.03 & 522.16 \\
\hline & FR & 32.67 & 0.05 & 4.94 & 344.88 & 4.46 & 75.17 & 104.11 & 577.80 \\
\hline & $\mathrm{D}$ & 29.25 & 0.00 & 1.69 & 201.15 & 2.47 & 43.08 & 36.75 & 74.43 \\
\hline & SK & 29.75 & 0.00 & 2.04 & 239.72 & 3.68 & 47.42 & 0.02 & 83.13 \\
\hline \multirow{7}{*}{ Bojos } & $C Z$ & 20.71 & 0.00 & 0.63 & 267.12 & 3.24 & 69.03 & 140.46 & 84.46 \\
\hline & $\mathrm{HU}$ & 8.71 & 0.00 & 0.70 & 241.11 & 2.89 & 64.14 & 139.91 & 61.70 \\
\hline & PL & 11.93 & 0.00 & 1.84 & 131.07 & 0.33 & 21.20 & 129.06 & 28.19 \\
\hline & NL & 11.56 & 0.00 & 1.93 & 316.29 & 3.38 & 75.74 & 131.82 & 400.93 \\
\hline & FR & 23.58 & 0.00 & 5.19 & 346.20 & 3.72 & 76.13 & 138.59 & 492.59 \\
\hline & $\mathrm{D}$ & 17.84 & 0.00 & 4.14 & 296.51 & 2.32 & 66.04 & 134.37 & 418.27 \\
\hline & SK & 18.7 & 0.00 & 0.6 & 296.6 & 3.8 & 62.9 & 140.1 & 55.9 \\
\hline
\end{tabular}

CZ - Czech Republic; HU - Hungary; PL - Poland; NL - Netherlands; FR - France; D - Germany; SK - Slovakia

C - catechin; (E)C - epicatechin; (E)GC - gallocatechin and epigallocatechin; (E)C-(E)C - dimers of catechin/epicatechin bond with other catechin or epicatechin structural unit; (E)C-(E)A - dimers of catechin/epicatechin with afzelechin or epiafzelechin structural unit;

(E)C-(E)C-(E)C - trimers of catechin/epicatechin structural units; (E)GC-(E)GC - dimers of gallocatechin/epigallocatechin with gallocatechin or epigallocatechin structural units; (E)C-(E)GC - dimers of catechin/epicatechin with gallocatechin or epigallocatechin structural units

catechin structural unit $/(E) \mathrm{C}-(E) \mathrm{C} /, 7$ trimers consisting of catechin and epicatechin structural units in the various orders /(E)C- $(E) \mathrm{C}-(E) \mathrm{C} /, 2$ dimers of catechin/ epicatechin with afzelechin or epiafzelechin structural unit /(E)C-(E)A/, 7 different dimers consisting of various combinations of catechin/epicatechin with gallocatechin or epigallocatechin /(E) C-(E)GC/ and 4 dimers of gallocatechin/epigallocatechin with gallocatechin or epigallocatechin structural unit units /(E)GC- $(E) \mathrm{GC} /$. The most abundant proanthocyanidins in barley malt samples were identified as Procyanidin B3, a dimer of catechin units (C- $(4 \alpha \rightarrow 8)-C)$; Prodelphinidin B3, a dimer of gallocatechin and catechin units (GC- $(4 \alpha \rightarrow 8)-C)$; and the trimer Procyanidin $\mathrm{C} 2$ consisting of three catechin units (C- $(4 \alpha \rightarrow 8)-C-(4 \alpha \rightarrow 8)-C)$. The profile of most abundant proanthocyanidins in analyzed barley samples was in accordance with data previously published by Zimmermann \& Galensa (2007).
In accordance with published data, the results show that dimers and trimers are dominant in the PAC malt profile. The bulk part was formed by dimers (E)C-(E)C $(37.0 \%$ rel.) and $(E) \mathrm{C}-(E) \mathrm{G}(36.4 \%$ rel. on average), less represented were dimers $(E) C-(E) G(136 \%$ Rel. on average) and trimers $(E) C-(E) C-(E) C$ (8.6\% rel.). The content of monomers, (epi) gallocatechin $(0.5 \%$ rel.) and (epi) catechin $(3,3 \%$ rel.) was low. In contrast to hops, the proportion of dimeric and trimeric catechins in malt predominates, monomers, catechin and epicatechin being dominant (Olšovská et al., 2013). Figure 2 shows the average values of the individual groups of proanthocyanidins according to the growing locations and varieties; Figure 3 shows the relative representation of the proanthocyanidins groups. The sum of proanthocyanidins appeared to be dependent on the locality (country), malts from Poland (PL), Slovakia (SK) and Germany (D) were below the average of the whole tested group, the highest values being 


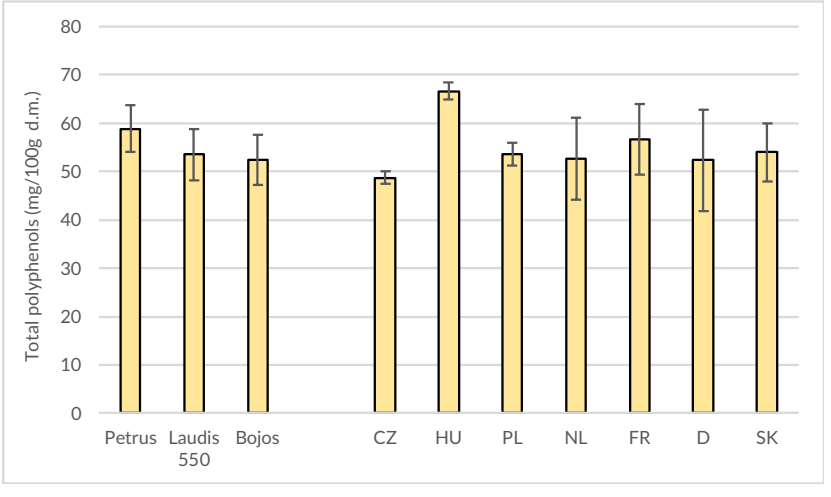

Figure 1 Comparison of total polyphenols in malt by variety and locality

CZ - Czech Republic; HU - Hungary; PL - Poland; NL - Netherlands; FR - France; D - Germany; SK - Slovakia
Figure 2 Profile of oligomeric proanthocyanidin content in malts

CZ - Czech Republic; HU - Hungary; PL - Poland;

NL - Netherlands; FR - France; D - Germany; SK - Slovakia

C - catechin; (E)C - epicatechin; (E)GC - gallocatechin and epigallocatechin; (E)C-(E)C - dimers of catechin/epicatechin bond with other catechin or epicatechin structural unit; (E)C-(E)A dimers of catechin/epicatechin with afzelechin or epiafzelechin structural unit; $(E) C-(E) C-(E) C$ - trimers of catechin/epicatechin structural units; (E)GC-(E)GC - dimers of gallocatechin/epigallocatechin with gallocatechin or epigallocatechin structural units; (E)C-(E)GC - dimers of catechin/epicatechin with gallocatechin or epigallocatechin structural units

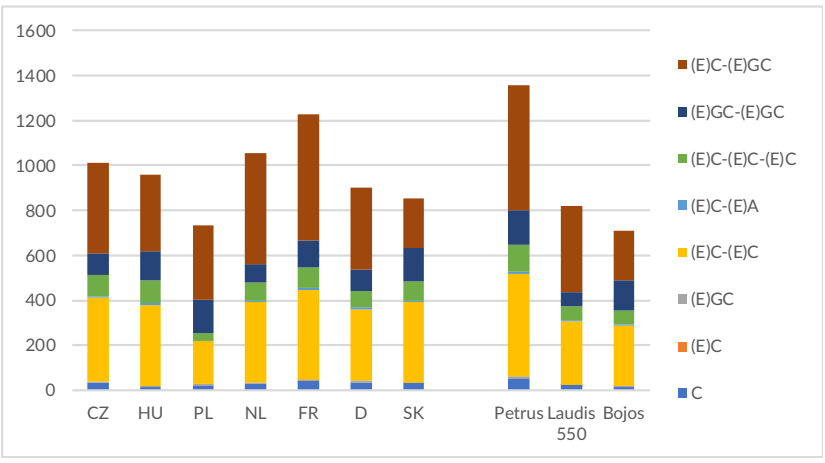

Figure 3 Relative representation of oligomeric proanthocyanidins in malts

CZ - Czech Republic; HU - Hungary; PL - Poland; NL - Netherlands; FR - France; D - Germany; SK - Slovakia

$C$ - catechin; (E)C - epicatechin; (E)GC - gallocatechin and epigallocatechin; (E)C-(E)C - dimers of catechin/epicatechin bond with other catechin or epicatechin structural unit; $(E) C-(E) A-$ dimers of catechin/epicatechin with afzelechin or epiafzelechin structural unit; $(E) C-(E) C-(E) C$ - trimers of catechin/epicatechin structural units; (E)GC-(E)GC - dimers of gallocatechin/epigallocatechin with gallocatechin or epigallocatechin structural units; (E)C-(E)GC - dimers of catechin/epicatechin with gallocatechin or epigallocatechin structural units
Figure 4 Cluster analysis of relative representation of proanthocyanidins in malt

CZ - Czech Republic; HU - Hungary; PL - Poland; NL - Netherlands; FR - France; D - Germany; SK - Slovakia PET - Petrus; LAU - Laudis 550; BOJ - Bojos

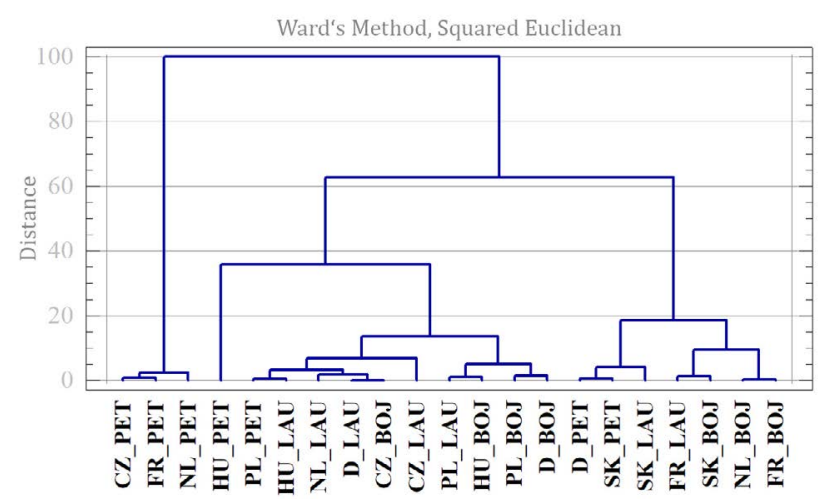


recorded for malts from France (FR). By contrast, the varietal effect was strong, significant at the $P=0.001$; for Petrus malts, the average PAC values were almost twice as high as the Bojos or Laudis 550 malts (Figure 2). Differences between Petrus malts and other varieties in total polyphenols were smaller compared to differences in PAC content. Varietal dependence in the ratio of flavonoids and phenolic acids can be indirectly derived from the results of the assessment of PAC and total polyphenols.

Relative representation of individual groups of proanthocyanidins appeared to be dependent on the variety and locality Cluster analysis of the data (Figure 4) showed, for example, a narrow cluster of samples of the variety Petrus with the exception of a sample from Poland or a grouping of Bojos samples from four neighboring countries (CZ, HU, SK, PL). On the other hand, samples of Petrus and Laudis 550 from Poland were diametrically different from those of these varieties from the other six countries.

Flavanols, flavonols and their glycosides: The results of the determination of the content of flavanols (catechins), flavonols and their glycosides in malts are summarized in Table 3. The results are given in $\mu \mathrm{g} / \mathrm{L}$ of wort. Figure 5 shows the average values of the individual substances after the localities and varieties; Figure 6 shows the relative representation of the individual polyphenol compounds.

The flavanols catechin, epicatechin, catechin-0-glucoside and epicatechin-0-glucoside have Been identified and quantified in worts. Of the flavonol family, quercetin and myricetin were found, while flavonol glycosides were not detected in wort samples. In the profile of flavonoid polyphenols of malt, the majority share is represented by catechin $(1600-3600 \mu \mathrm{g} / \mathrm{L}$, $60-70 \%$ of the sum) and catechin-O-glucoside (500$1100 \mu \mathrm{g} / \mathrm{L}, 20-25 \%$ of the sum). The content of flavonols was an order of magnitude lower, concentration of quercetin And myricetin was about $20 \mu \mathrm{g} / \mathrm{L}$ and $80 \mu \mathrm{g} / \mathrm{L}$, respectively. It is evident that the amount of These substances present in malt, or transferred from malt to wort, is very low. The total amount of the determined flavonoid polyphenols strongly depended on the variety $(\mathrm{P}=0.0001)$, the highest values were found in the Petrus malts, and this value also depended on the locality $(P=0.006)$. The lowest flavonoids were featured by malts from Hungary, while the highest values were detected in malts from Poland and Slovakia.

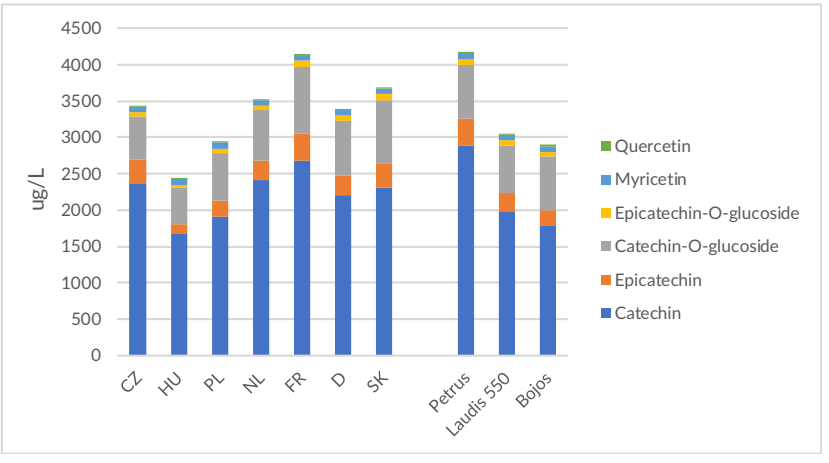

Figure 5 Profile of the content of flavanols, flavonols and their glycosides in malts (wort)

CZ - Czech Republic; HU - Hungary; PL - Poland; NL - Netherlands; FR - France; D - Germany; SK - Slovakia

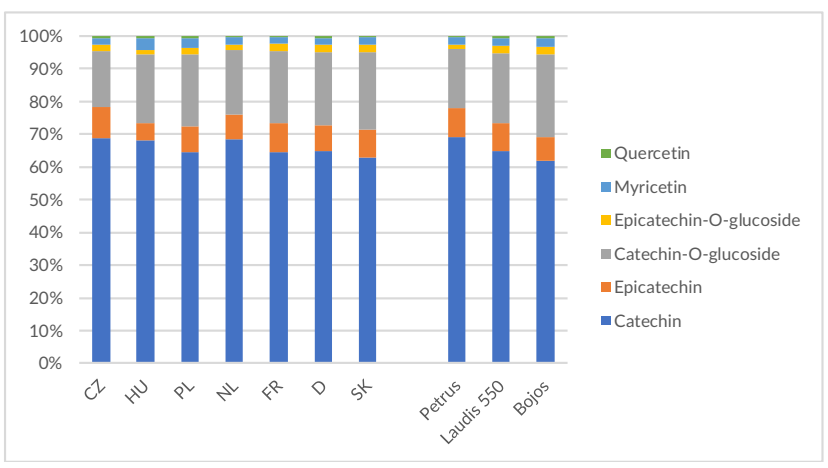

Figure 6 Relative representation of flavanols, flavonols and their glycosides in malts (wort)

CZ - Czech Republic; HU - Hungary; PL - Poland; NL - Netherlands; FR - France; D - Germany; SK - Slovakia

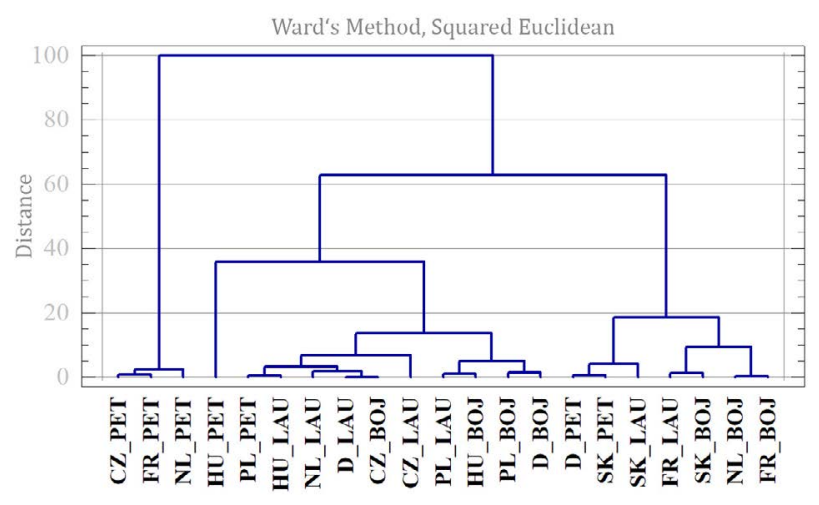

Figure 7 Cluster analysis of relative representation of flavanols, flavonols and their glycosides in malts

CZ - Czech Republic; HU - Hungary; PL - Poland;

NL - Netherlands; FR - France; D - Germany; SK - Slovakia

PET - Petrus; LAU - Laudis 550; BOJ - Bojos 
Table 3 Effect of variety and country of origin on concentrations of flavanols, flavonols and their glycosides in wort (ug/L)

\begin{tabular}{|c|c|c|c|c|c|c|c|}
\hline$\frac{\vec{y}}{\frac{\pi}{20}}$ & 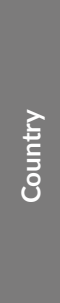 & $\begin{array}{l}\frac{5}{\mathrm{c}} \\
\frac{\mathrm{J}}{\mathrm{J}} \\
\text { U. }\end{array}$ & 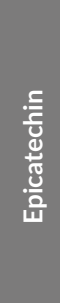 & 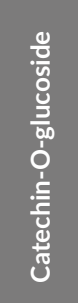 & 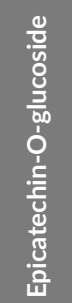 & 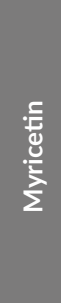 & 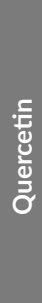 \\
\hline \multirow{7}{*}{ Bojos } & $\mathrm{CZ}$ & 1894 & 190 & 656 & 52 & 73 & 17 \\
\hline & $\mathrm{HU}$ & 1571 & 134 & 562 & 39 & 78 & 18 \\
\hline & $\mathrm{PL}$ & 1604 & 188 & 637 & 57 & 74 & 17 \\
\hline & NL & 1708 & 196 & 836 & 75 & 70 & 16 \\
\hline & FR & 2111 & 240 & 1047 & 90 & 79 & 18 \\
\hline & $\mathrm{D}$ & 1634 & 160 & 620 & 49 & 71 & 16 \\
\hline & SK & 2047 & 330 & 805 & 97 & 77 & 18 \\
\hline \multirow{7}{*}{ Laudis 550} & $C Z$ & 2015 & 353 & 535 & 77 & 76 & 17 \\
\hline & $\mathrm{HU}$ & 1782 & 191 & 503 & 47 & 75 & 17 \\
\hline & $\mathrm{PL}$ & 1572 & 159 & 553 & 46 & 74 & 17 \\
\hline & $\mathrm{NL}$ & 2072 & 219 & 620 & 57 & 74 & 17 \\
\hline & FR & 2332 & 384 & 904 & 121 & 81 & 18 \\
\hline & $\mathrm{D}$ & 1936 & 209 & 653 & 56 & 75 & 17 \\
\hline & SK & 2147 & 262 & 811 & 81 & 74 & 17 \\
\hline \multirow{7}{*}{ Petrus } & $\mathrm{CZ}$ & 3176 & 444 & 598 & 59 & 72 & 17 \\
\hline & $\mathrm{HU}$ & 1641 & 75 & 467 & 16 & 104 & 24 \\
\hline & $\mathrm{PL}$ & 2548 & 339 & 766 & 74 & 106 & 24 \\
\hline & $\mathrm{NL}$ & 3466 & 384 & 613 & 51 & 80 & 18 \\
\hline & FR & 3610 & 470 & 791 & 71 & 77 & 17 \\
\hline & $\mathrm{D}$ & 3024 & 439 & 1026 & 111 & 75 & 17 \\
\hline & SK & 2755 & 384 & 982 & 93 & 77 & 18 \\
\hline
\end{tabular}

CZ - Czech Republic; HU - Hungary; PL - Poland; NL - Netherlands; FR - France; D - Germany; SK - Slovakia

\section{Conclusion}

Polyphenol substances are important in the brewing industry for both colloidal status and antioxidant status of beer; the latter could be reflected in the flavor stability of the product, and could have beneficial health effects when consuming beer. Therefore, their research in brewing raw materials and beer is still needed. The methods to determine the PAC profile and flavonoid polyphenols developed in this work have proven to be a satisfactory tool for research on these compounds in malt. The measured PAC data is in good agreement with the published results. The results of our pilot study of the flavonoid profile in malts suggest varietal dependence of the amount and profile of proanthocyanidins as well as the profile of monomeric flavanols, flavonols and glycosides of these substances, and probably a lesser impact of the growing locality and soil-climatic conditions within different European countries. Given the small number of varieties in the study, we will address this issue in the next work.

\section{Acknowledgements}

The study was supported by the Ministry of Education, Youth and Sports of the Czech Republic, project L01312.

\section{References}

Analytica-EBC, 2010. Nürenberg, Fachverlag Hans Carl, 2010. ISBN: 9783-418-00759-5.

Anastassiades M, Lehotay SJ, Stajnbaher D, Schenck FJ., 2003. Fast and easy multiresidue method employing acetonitrile extraction/partitioning and "dispersive solid-phase extraction" for the determination of pesticide residues in produce. Journal of AOAC International $86(2): 412-431$ 
Aron, PM., Shellhammer, TH., 2010, A Discussion of Polyphenols in Beer Physical and Flavour Stability. Journal of the Institute of Brewing 116(4): 369-380. https://doi.org/10.1002/j.2050-0416.2010.tb00788.x

Basařová, G., Šavel, J., Basař, P., Lejsek, K.: Pivovarství. Teorie a praxe výroby piva (Brewing. Theory and Practice of Beer Production). Praha, VŠCHT, 2010, 863 p. ISBN 978-80-7080-734-7. In Czech.

Basařová, G., Šavel, J., Basař, P., Lejsek, K.: Pivovarství. Teorie a praxe výroby piva (Brewing. Theory and Practice of Beer Production). Praha, VŠCHT, 2010, 863 p. ISBN 978-80-7080-734-7. In Czech.

Bocquet L, Sahpaz S, Riviere C (2018a) An overview of the antimicrobial properties of hop. In: Merillon JM, Riviere C (eds) Natural antimicrobial agents, series sustainable development and biodiversity. Springer, New York, pp 31-54. https://doi.org/10.1007/978-3-31967045-4_2

Bocquet, L., Sahpaz, S., Hilbert, J. L., Rambaud, C., Rivie`re, C., 2018. Humulus lupulus L., a very popular beer ingredient and medicinal plant: overview of its phytochemistry, itsbioactivity, and its biotechnology. Phytochemistry Reviews 17:1047-1090. https://doi.org/10.1007/ s11101-018-9584-y

Callemien, D., Bennani, M., Counet, C., Collin, S., 2005. Which polyphenols are involved in aged ber astringency? Assessment by HPLC and time-intensity method. In: Proceedings of the 30th EBC Congress, Prague 2005. Nuremberg: Fachverlag Hans Carl, 2005, 809-814.

Callemien, D., Collin, S., 2010. Structure, organoleptic properties, quantification methods, and stability of phenolic compounds in beer a review. Food Reviews International 26:1-84. https://doi. org/10.1080/87559120903157954

Commission, 2008: Publication of an application pursuant to Article 6(2) of Council Regulation (EC) No 510/2006 on the protection of geographical indications and designations of origin for agricultural products and foodstuffs. Official Journal of the European Union C 16-22.

Derdelinckx, G., 2008. Polyphenols in wort and beer: State of art in 2008: Where and why? Cerevisia 33 (4): 174-187.

Dvorakova, M., Douanier, M., Jurkova, M., Kellner, V., Dostalek, P., 2008a. Comparison of antioxidant activity of barley (Hordeum vulgare L.) and malt extracts with the content of free phenolic compounds measured by high performance liquid chromatography coupled with CoulArray detector. Journal of the Institute of Brewing 114(2): 150159. https://doi.org/10.1002/j.2050-0416.2008.tb00320.x

Dvořáková, M., Guido, LF, Dostálek, P., Skulílová, Z., Moreira, MM. , Barros, A A., 2008. An-tioxidant Properties of Free, Soluble Ester and Insoluble-Bound Phenolic Compounds in Different Barley Varieties and Corresponding Malts. Journal of the Institute of Brewing 114(1), 2733. https://doi.org/10.1002/j.2050-0416.2008.tb00302.x

Gangopadhyay, N., Rai, D. K., Brunton, N. P., Gallagher, E., \& Hossain, M. B. (2016). Antioxidant-guided isolation and mass spectrometric identification of the major polyphenolsin barley (Hordeum vulgare) grain. Food Chemistry, 210, 212-220. https://doi.org/10.1016/j. foodchem.2016.04.098

Guido, LF., Curto, AF., Boivin, P., Benismail, N., Goncalves, CR., Barros, AA.,2007. Correlation of Malt Quality Parameters and Beer Flavor Stability: Multivariate Analysis. Journal of Agricultural and Food Chemistry 55: 728-733. https://doi.org/10.1021/jf0623079

Kahkonen, M. P., I, H. A., Vuorela, H. J., Rauha, J.-P., Pihlaja, K., Kujala, T. S., \& Heinonen, M. (1999). Antioxidant activity of plant extracts containing phenolic compounds. Journal of Agricultural and Food Chemistry, 47, 3954-3962. https://doi.org/10.1021/jf990146l

Karabín, M., Hudcová, T., Jelínek, L., Dostálek, P., 2016. Biologically Active Compounds from Hops and Prospects for Their Use. Comprehensive Reviews in Food Science and Food Safety 15, 1-26. https://doi.org/ 10.1111/1541-4337.12201
Lotito, S. B., Actis-Goretta, L., Renart, M., Caligiuri, M., Rein, D., Schmitz, H. H., Steinberg, F. M., Keen, C. L., Fraga, C. G., 2000. Influence of Oligomer Chain Length on the Antioxidant Activity of Procyanidins. Biochemical and Biophysical Research Communications, 276: 945-951. http://doi:10.1006/bbrc.2000.3571

Maatta-Riihinen, K R.; Kahkonen, MP.; Torronen, AR.; Heinonen, IM, 2005. Catechins and procyanidins in berries of Vaccinium species and their antioxidant activity. Journal of Agricultural and Food Chemistry 53: 8485-8491. https://doi.org/10.1021/jf0504081

Mareček,V., Mikyška, A., Hampel, D., Čejka, P., Neuwirthová, L., Malachová, A., Cerkal, R. (2017): ABTS and DPPH methods as a tool for studying antioxidant capacity of spring barley and malt. Journal of Cereal Science, 72, 40-45. https://doi.org/10.1016/j.jcs.2016.11.004

McLaughlin, I. R., Lederer, C., Shellhammer, T.H., 2008. Bitterniss-modifying properties of hop polyphenols extracted from spent hop material. Journal of American Society of Brewing Chemists 66(3): 174-183. https://doi.org/10.1094/ASBCJ-2008-0619-01

Merghem, R., Jay, M., Brun, N., Voirin, B., 2004. Qualitative analysis and HPLC isolation and identification of procyanidins from Vicia faba. Phytochemical Analysis 15: 95-99. https://doi.org/10.1002/ pca.731

Mikyška, A., Krofta, K. (2012): Assessment of changes in hop resins and polyphenols during long-term storage. J. Inst. Brew., 118(3): 269279. https://doi.org/10.1002/jib.40

Narziss, L., \& Bellmer, H. G. (1975). Veranderungen der Polyphenole und ihres P. I. Wahrend des Hopfenkochens in Wasser und Wurze. Brauwissenschaft, 28(11), 323-343.

Narziss, L. (1976). Polyphenolgehalt und Polymerisationsindex von Gersten und Kleinmalzen. Monatsschrift fur Brauwissenschaft, 29(1), 9-19.

Nowak, R., Olech, M., Nowacka, N., 2014. Plant polyphenols as chemopreventive agents. In: Watson R, Preedy V, Zibadi S, editors. Polyphenols in human health and disease. San Diego: Elsevier Inc. P 1289-307. https://doi.org/10.1016/B978-0-12-398456-2.00086-4

Oladokun, O., Tarrega, A., James, S., Smart, K., Hort, J., Cook, D., 2016. The impact of hop bitter acid and polyphenol profiles on the perceived bitterness of beer. Food Chemistry 205: 2012-220. https://doi. org/10.1016/j.foodchem.2016.03.023

Olšovská J, Kameník Z, Čejka P, Jurková M, Mikyška A (2013) Ultra-high-performance liquid chromatography profiling method for chemical screening of proanthocyanidins in Czech hops. Talanta 116:919-926. https://doi.org/10.1016/j.talanta.2013.07.067

Quinones, M., Miguel M., Aleixandre A. 2013. Benefitial effects of polyphenols on cardiovascular disease. Pharmacological Research 6,8:125131. https://doi.org/10.1016/j.phrs.2012.10.018

Stevens, J.F., Miranda, C. R., Buhler, D.R.: Chemistry and biochemistry of hop flavonoids. Journal of American Society of Brewing Chemists 56(4), 1998, 136-145. https://doi.org/10.1094/ASBCJ-56-0136

Taylor, A. W., Barofsky, E. L., Kennedy, J. A., \& Deinzer, M. L. (2003). Hop (Humulus lupulus l.) proanthocyanidins characterized by mass spectrometry, acid catalysis, and gel permeation chromatography. Journal of Agricultural and Food Chemistry, 51, 4101-4110. https://doi. org/10.1021/jf0340409

Zimmermann, B. F., \& Galensa, R. (2007). One for all- all for one: Proof of authenticity and tracing of foods with flavonoids - analysis of proanthocyanidins in barley and malt. European Food Research and Technology, 224(3), 385-393. https://doi.org/10.1007/s00217-006-033 